\title{
Insight into the role of phosphatidylserine in complement-mediated synapse loss in Alzheimer's disease
}

\author{
Dimitra Sokolova ${ }^{1, \mathrm{X}} \quad$ Thomas Childs $1, \mathrm{X} \quad$ Soyon Hong (iD ${ }^{1 *}$ \\ ${ }^{1}$ UK Dementia Research Institute, Institute of Neurology, University College London, Gower Street, London WC1E 6BT, UK \\ ${ }^{\mathrm{x}}$ These authors contributed equally to this work
}

\begin{abstract}
The innate immune system plays an integral role in the brain. Synaptic pruning, a fundamental process in developmental circuit refinement, is partially mediated by neuroimmune signalling at the synapse. In particular, microglia, the major tissue-resident macrophages of the brain, and the classical complement cascade, an innate immune pathway that aids in the clearance of unwanted material, have been implicated in mediating synapse elimination. Emerging data suggest that improper signalling of the innate immune pathway at the synapse leads to pathological synapse loss in age-related neurodegenerative diseases, including Alzheimer's disease. Now the key questions are whether synapses are targeted by complement and, if so, which synapses are vulnerable to elimination. Here, we review recent work implicating C1q, the initiator of the classical complement cascade, and surrounding glia as mediators of synapse loss. We examine how synapses could undergo apoptosis-like pathways in the Alzheimer brain, which may lead to the externalisation of phosphatidylserine on synapses. Finally, we discuss potential roles for microglia and astrocytes in this 'synaptic apoptosis'. Critical insight into neuroimmune regulatory pathways on synapses will be key to developing effective targets against pathological synapse loss in dementia.
\end{abstract}

\section{Keywords}

Alzheimer's disease, mitochondrial dysfunction, synapse loss, classical complement cascade, microglia, astrocyte, phosphatidylserine, synaptosis, caspase-3, MFG-E8, TAM, TREM2

\section{Peer Review}

The peer reviewers who approve this article are:

1. Morgan Sheng, Stanley Center for Psychiatric Research, Broad Institute of MIT and Harvard, Cambridge, MA, 02142, USA Competing interests: Morgan Sheng is a member of the Board of Directors for Prevail Therapeutics, a Co-Founder and SAB member for RBNC, consults for Genentech Inc, and is an SAB member for Biogen Inc and Cerevel Therapeutics, LLC.

2. Cynthia Lemere, Ann Romney Center for Neurologic Diseases, Brigham and Women's Hospital, Building for Transformative Medicine, 9th Floor, 60 Fenwood Road, Boston, MA 02115, USA

Competing interests: No competing interests were disclosed.

3. Won-Suk Chung, Department of Biological Sciences, Korea Advanced Institute of Science and Technology (KAIST), Daejeon, Korea

Competing interests: No competing interests were disclosed. 
*Corresponding author: Soyon Hong (soyon.hong@ucl.ac.uk)

Competing interests: The following patents have been granted or applied for: PCT/2015/010288, US14/988387 and EP14822330 (S.H.). All the other authors declare that they have no competing interests.

Grant information: This work was supported by the UK Dementia Research Institute (SH), which receives its funding from DRI Ltd, the UK

Medical Research Council, Alzheimer's Society and Alzheimer's Research UK (SH), the Collaborative Pairs project of the Chan Zuckerberg Initiative (SH), AstraZeneca UK Limited (DS) and the Biotechnology and Biological Sciences Research Council (DS).

The funders had no role in study design, data collection and analysis, decision to publish, or preparation of the manuscript.

Copyright: ( 12021 Hong S et al. This is an open access article distributed under the terms of the Creative Commons Attribution License, which permits unrestricted use, distribution, and reproduction in any medium, provided the original work is properly cited.

How to cite this article: Sokolova D, Childs $\mathrm{T}$ and Hong $\mathrm{S}$. Insight into the role of phosphatidylserine in complement-mediated synapse loss in Alzheimer's disease. Faculty Reviews 2021 10:(19) https://doi.org/10.12703/r/10-19

Published: 24 Feb 2021, Faculty Reviews 10:(19) https://doi.org/10.12703/r/10-19 


\section{Introduction}

Genetic studies in Alzheimer's disease (AD) implicate microglia, the major resident immune cells of the brain, as modulators for the risk of dementia ${ }^{1-5}$. Studies in animal models of AD suggest that microglia may contribute to the risk by acting as cellular mediators of synapse $\operatorname{loss}^{6-11}$. One proposed mechanism for the microglia-mediated synapse loss involves a region-specific reactivation of an innate immune pathway called the classical complement cascade, which has been shown to play a critical role in developmental synaptic pruning ${ }^{12,13}$. However, what triggers this reactivation of the complementmediated synapse pruning pathway is unclear. In particular, how synapses may be lost in $\mathrm{AD}$ is a critical question that needs to be elucidated. Literature in AD models suggests an interesting concept of 'synaptosis', whereby focal apoptotic cascades at dendritic spines can occur in the absence of neuronal death ${ }^{14-16}$. This raises the intriguing questions of whether complement-mediated synapse loss by microglia in $\mathrm{AD}$ requires synaptosis and, if so, how. Here, we summarise emerging data from developing and diseased brains which suggest a role for phosphatidylserine (PtdSer), a canonical 'eat me' signal on apoptotic cells, in synapse loss. We then discuss potential links between externalised phosphatidylserine (ePtdSer), complement $(\mathrm{C} 1 \mathrm{q}$ and $\mathrm{C} 3)$ and receptors on microglia and astrocytes that could be involved in the recognition of ePtdSer. Furthermore, we speculate on whether and how ePtdSer may act as a signal for synaptosis in the AD brain. Synapse loss is a significant correlate of cognitive impairment in $\mathrm{AD}^{17-22}$. Therefore, critical insight into mechanisms mediating synapse loss has the potential to identify effective therapeutic targets against cognitive decline and alter $\mathrm{AD}$ prognosis.

\section{Complement-mediated synapse loss}

A universal hallmark of neurologic diseases is the region-specific vulnerability of neurons and neuronal networks to dysfunction and loss ${ }^{23}$. Hence, a long-standing question in neurobiology has been what contributes to the region-specific loss of synapses and neurons. In $\mathrm{AD}$, synapse loss strongly correlates with cognitive impairment ${ }^{17-22}$ and appears to be present before overt neuronal $\operatorname{loss}^{24,25}$. Data from multiple laboratories collectively suggest that synaptic failure and loss in $\mathrm{AD}$ are likely initiated by pre-fibrillar oligomers of amyloid-beta $(A \beta)$ and tau at synapses ${ }^{6,26-33}$. However, precise mechanisms of how these oligomers initiate synapse loss and dysfunction need further investigation.

Insight into the role of the innate immune pathway in synapse loss stemmed from post-natal circuit refinement in the developing mouse brain. Synaptic pruning in the developing brain is a normal and highly regulated process, where supernumerary synapses are removed to obtain the appropriate number of synapses $^{34}$. Multiple mechanisms have been shown to mediate synaptic refinement in the developing brain, depending on brain regions and timepoints ${ }^{35,36}$. These include immune pathways such as fractalkine signalling ${ }^{37,38}$ and triggering receptor expressed on myeloid cells 2 (TREM2) ${ }^{39}$ in the hippocampus, complement $(\mathrm{C} 1 \mathrm{q} / \mathrm{C} 3)^{12,13}$, MERTK-MEGF10 ${ }^{40}$ and IL-33 ${ }^{41}$ in the

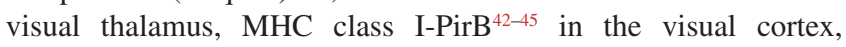
and fractalkine signalling and ADAM10 ${ }^{46}$ in the barrel cortex. Among these, the classical complement cascade (C1q and $\mathrm{C} 3$ ) has been shown to be reactivated in multiple models of neurologic diseases ${ }^{6,8-10,47-51}$. Complement proteins are innate immune molecules that act as 'eat me' signals to promote rapid clearance of invading pathogens or cellular debris ${ }^{52-55}$. One way the complement-bound materials are eliminated from the blood is via circulating macrophages ${ }^{53,56}$. At the peak synaptic pruning period in the developing visual thalamus, microglia engulf synapses in a complement (C3-CR3)- and neuronal activity-dependent manner ${ }^{13}$. When the critical pruning window is largely over, complement $(\mathrm{C} 1 \mathrm{q}$ and $\mathrm{C} 3)$ activation appears to be down-regulated ${ }^{12,13,57}$. Disruption of complement pruning pathway results in sustained defects on synaptic connectivity ${ }^{12,13,58,59}$, suggesting a fundamental role for the classical complement cascade in brain wiring. Interestingly, a recent study suggested a possible role for complement and microglia in the healthy adult mouse brain involving engram-related memory processes ${ }^{60}$, raising the intriguing question of whether immune pathways critical for synaptic pruning in developing brains contribute to normal synaptic plasticity in the steady-state healthy adult brain. With normal aging, there is a region-specific vulnerability of synapses to loss and dysfunction ${ }^{61}$, and $\mathrm{C} 1 \mathrm{q}$ and $\mathrm{C} 3$ have been shown to differentially affect age-dependent synaptic vulnerability $^{57,62}$. Together, these studies suggest that the classical complement cascade contributes to synaptic development, maintenance and function throughout the lifespan of an animal.

In $\mathrm{AD}$, complement activation was initially regarded as a secondary event related to peri-plaque neuropathology $\mathrm{y}^{63}$, as $\mathrm{C} 1 \mathrm{q}$, $\mathrm{C} 3$ and $\mathrm{C} 4$ are often found up-regulated and localised to neuritic plaques $^{64}$. Moreover, $A \beta$ plaques have been shown to bind and regulate the expression and localisation of complement ${ }^{65}$. However, genetic data suggest that complement may be more than bystanders of $\mathrm{AD}$ : among the risk variants for $\mathrm{AD}$ are $C L U$, also known as complement lysis inhibitor or APOJ, and $C R 1$, which encodes for the complement component $\mathrm{C} 3 \mathrm{~b}$ receptor ${ }^{66}$. Indeed, emerging data in both amyloid- and tau-induced mouse models of $\mathrm{AD}$ suggest that the classical complement cascade mediates synapse loss and dysfunction and cognitive impairment ${ }^{6,8-10,67}$. At pre-plaque ages of mouse models of AD (the J20 hAPP and APP/PS1 transgenic), C1q and $\mathrm{C} 3$ are reactivated in a brain region-specific manner and appear punctate and localised to synaptic proteins in vulnerable brain regions ${ }^{6}$. In addition, microglia were found to engulf synaptic proteins in a CR3-dependent manner ${ }^{6}$. Importantly, genetic or antibody means of blocking C1q, C3 or CR3 protect synapses from $\mathrm{A} \beta$-induced loss and dysfunction and downstream cognitive impairment ${ }^{6,8,10}$. These findings corroborate those of an earlier study where Clqa-deficient mice crossed with the Tg2576 hAPP mouse model resulted in less plaque-related neuronal damage, synapse loss and gliosis compared with Clqa-sufficient mice $^{67}$. Similarly, in the Tau-P301S model, 
unbiased proteomics of hippocampal post-synaptic densities (PSDs) revealed $\mathrm{Clq}$ as the most highly up-regulated protein relative to wild-type mice ${ }^{9}$. Injecting anti-C1q functional blocking antibody into the hippocampus of these mice attenuated the loss and microglial engulfment of synaptic proteins? In addition, levels of $\mathrm{C} 1 \mathrm{q}$ also positively correlated with levels of phospho-tau in PSDs from the temporal cortex of $\mathrm{AD}$ human brains ${ }^{9}$. Genetic deletion of $C 3$ also rescued neurodegeneration in the Tau-P301S model ${ }^{10}$. Together, these data suggest that the classical complement cascade is reactivated in AD-like brains and mediates synapse loss and dysfunction. Interestingly, inhibiting ${ }^{68}$ or deleting ${ }^{69} \mathrm{C} 3$ in one APP mouse model (the J20) resulted in increased plaque-related neurodegeneration whereas $\mathrm{C} 3$ deletion in other mouse models (APP/PS1 ${ }^{8}$ and $\mathrm{PS} 2 \mathrm{APP}^{10}$ ) resulted in an amelioration of plaque-related neurodegeneration. In a tau-based model, $C 3$ deletion was protective for neuron loss and brain atrophy ${ }^{10}$. This apparent discrepancy could have stemmed from major differences in the mouse models themselves ${ }^{8}$. However, it is important to note that, despite increased levels of plaques, synapses were still protected from loss and memory was intact in the aged APP/PS1 mice ${ }^{8}$. These studies together suggest that complement is activated in the brain in various contexts to clear what is deemed as 'debris' (for example, synapses as well as plaques). Therefore, understanding what on synapses reactivates complement for microglial elimination will be a critical question for the AD field to assess $^{1}$.

\section{Understanding the molecular determinants of synaptic vulnerability in Alzheimer's disease}

Apoptosis-like events on synapses in Alzheimer's disease

Apoptosis, a process of programmed cell death involving caspase-3 activation, has an essential role in triggering the removal of damaged or dying cells by the immune system ${ }^{55}$. Interestingly, $A \beta$-induced synaptic impairment was ameliorated in caspase-3-deficient rodent models, suggesting that caspase-3 activation is important for $A \beta$-induced synaptic dysfunction ${ }^{70}$. Caspase-3 activation within hippocampal neurons has been shown to be essential for regulation of spine density and dendrite morphology ${ }^{71}$. Synaptotoxic $A \beta$ species appear to activate local apoptotic cascades, including the cleavage of caspase-3, in synaptosomes and dendrites ${ }^{14}$. Cleaved caspase-3 levels are increased in post-synaptic densities from post-mortem AD human brains ${ }^{72}$ and in hippocampal synaptosomes of pre-plaque $\operatorname{Tg} 2576$ hAPP mice at the onset of memory decline and spine loss ${ }^{15}$. These findings collectively suggest that caspase- 3 activity contributes to the loss and dysfunction of dendritic spines in $\mathrm{AD}$ models and support the notion of focal apoptotic cascades at synapses (that is, 'synaptosis') ${ }^{73,74}$. Furthermore, cleaved caspase-3 immunoreactivity was found in spines but not in neuronal soma or pre-synaptic terminals of the Tg2576 hAPP mice $^{15}$, suggesting a potential selective vulnerability of spines in this synaptosis paradigm. Some intriguing questions are whether apoptotic synapses are specifically removed by the immune system and, if so, what mediates this.
A role for externalised phosphatidylserine at the synapse

A fundamental mechanism employed by the immune system to eliminate damaged or dying cells is the recognition by macrophages of 'eat me' and 'don't eat me' signals expressed on the cell surface ${ }^{55}$. PtdSer is a membrane phospholipid that acts as an 'eat me' signal on apoptotic cell surfaces ${ }^{55}$. PtdSer is normally asymmetrically localised to the inner leaflet of the plasma membrane, but as cells undergo apoptosis, PtdSer is externalised to the outer leaflet. Cleavage of caspase- 3 activates flippases such as ATP11A and ATP11C and inactivates scramblases such as $\mathrm{Xkr8}$, which promote the externalisation and internalisation of PtdSer, respectively ${ }^{75-77}$. ePtdSer on the surface of apoptotic cells then is recognised as an 'eat me' signal by macrophages for phagocytosis ${ }^{55}$. Interestingly, ePtdSer has also been proposed to act as a ligand for $\mathrm{C} 1 \mathrm{q}$ on apoptotic cells and this binding of $\mathrm{Clq}$ to apoptotic cells is inhibited with annexin $\mathrm{V}$, a known PtdSer-binding protein ${ }^{78}$. Recent studies in the developing brain suggest that ePtdSer levels are increased on pre-synaptic compartments during critical periods of circuit refinement ${ }^{79,80}$. Furthermore, ePtdSer-positive neuronal terminals were found within lysosomal compartments of microglia and this localisation was ameliorated in Clqa knockout mice ${ }^{79}$. These data suggest a potential role for ePtdSer on synapses as a molecular target of $\mathrm{C} 1 \mathrm{q}$ deposition and subsequent microglial engulfment. In the Tg2576 hAPP mouse model of $\mathrm{AD}$, there was an increase of ePtdSer on hippocampal synaptosomes at the onset of hippocampal-dependent memory impairment, synaptic alterations and spine loss ${ }^{15}$. However, whether ePtdSer contributes to synapse loss in $\mathrm{AD}$ has yet to be shown.

\section{Potential links between mitochondrial dysfunction and synaptosis}

The activation of caspase-3 on dendritic spines of $\mathrm{Tg} 2576$ hAPP mice appears to be dependent on apoptosomes ${ }^{15}$, which are apoptosis-mediating protein complexes formed following the release of cytochrome $\mathrm{c}$ from mitochondria ${ }^{81}$. Furthermore, mitochondrial ATP synthase activity, which modulates levels of neuronal PtdSer externalisation ${ }^{82}$, has been shown to be impaired in $\mathrm{AD}$ mouse and human brains ${ }^{83-85}$, particularly in synaptic mitochondria ${ }^{85}$. These data suggest a possible link between synaptic mitochondria and synaptosis. In AD human brains, synaptosomes isolated from the temporal cortex have decreased levels of mitochondrial electron transport chain (ETC) complexes I, IV and V, along with an increased level of complement proteins in the same synaptosomes, relative to healthy control subjects ${ }^{86}$. Accordingly, proteomic analysis of the APP/PS1 transgenic mice showed altered levels of mitochondrial ETC proteins in $\mathrm{C} 1 \mathrm{q}$-associated synaptosomes ${ }^{87}$. It is unclear whether these findings are due to decreased protein expression, decreased localisation of mitochondria within synapses or due to preferential loss of mitochondria-rich synapses. However, reduction in the expression of mitochondrial oxidative phosphorylation genes in $\mathrm{AD}$ human brains has been shown at the mRNA level ${ }^{88}$. Furthermore, the activity of PtdSer 
flippases and scramblases can be modulated by $\mathrm{ATP}^{89-92}$, reactive oxygen species (ROS) $)^{93}$ and intracellular $\mathrm{Ca}^{2+}$ levels ${ }^{92-95}$. Mitochondria are critical for supplying ATP and $\operatorname{ROS}^{96,97}$ as well as buffering $\mathrm{Ca}^{2+}$ following synaptic activity ${ }^{97-99}$. The expression of mitochondrial $\mathrm{Ca}^{2+}$ efflux and influx genes is altered in post-mortem $\mathrm{AD}$ human brains ${ }^{100}$; and in hippocampal and cortical neurons from hAPP transgenic mice, the ability of mitochondria to buffer $\mathrm{Ca}^{2+}$ is impaired ${ }^{101,102}$. Furthermore, the levels of ROS are increased in synaptic mitochondria ${ }^{103}$ and synaptosomes $^{104}$ of pre-plaque hAPP mice relative to wildtype mice. These studies together raise the question of whether mitochondrial dysfunction leads to synapse loss and, if so, how. Further studies are needed to strengthen the role of synaptic mitochondria in synaptosis as well as potential links between synaptic $\mathrm{Ca}^{2+}$, ATP and ROS levels with ePtdSer.

\section{How apoptotic synapses may be recognised for elimination}

Tissue-resident macrophages recognise 'eat me' signals, such as ePtdSer, on apoptotic cells to mediate engulfment and clearance using a plethora of receptors ${ }^{55}$. Binding of ePtdSer by these receptors can be direct (for example, T-cell immunoglobulin and mucin domain containing 4, or TIM4) or indirect (for example, TYRO, AXL and MER [TAM] receptor tyrosine kinases and $\alpha 3 \beta 5$ and $\alpha 5 \beta 5$ integrins), the latter of which require ligands to bridge the interaction between receptor and ePtdSer such as GAS6, PROS1 and milk fat globule-EGF factor 8 protein (MFG-E8) $)^{55,105}$.

\section{Potential role for microglial TREM2 in synapse elimination}

Of particular interest is TREM2, which has been shown to mediate the clearance of apoptotic cells by macrophages in the brain $^{106-109}$. Genome-wide association studies identified mutations in TREM2, such as the $\mathrm{R} 47 \mathrm{H}$ loss-of-function variant ${ }^{110}$, as significantly altering the risk for developing $\mathrm{AD}^{111,112}$. One mechanism proposed for TREM2 is to act as an immune sensor to detect damage ${ }^{109,113}$. Lipids that accumulate after tissue damage or become externalised on apoptotic cells, such as ePtdSer on neuronal membranes, have been shown to activate TREM2 signalling ${ }^{108,114,115}$. In line with this, multiple studies in AD mouse models suggest that microglia with dysfunctional TREM2 are unable to sense $A \beta$ plaques and thus fail to form a putative protective barrier around plaques ${ }^{114-120}$. TREM2 has also been suggested to be a critical determinant of lipid metabolism in macrophages as well as microglial cell survival $^{115,121}$. In particular, functional knockouts of Trem 2 lead to the inability of microglia to adopt reactive phenotypes (the disease-associated microglia, or DAM $)^{120-124}$. Hence, proper TREM2 signalling may become even more crucial for brain health and homeostasis with aging. An intriguing idea is whether with aging, when the need to clear complement (C1q)-associated synapses increases ${ }^{57}$, aged microglia with decreased lipid metabolic and phagocytic capacity ${ }^{125}$ are unable to efficiently sense or clear what the brain regards as debris.
Loss-of-function mutations in TREM2 or DAP12, an adaptor protein for TREM2 signalling, underlie the Nasu-Hakola disease, in which patients display progressive presenile dementia ${ }^{126,127}$. These findings suggest that TREM2 may have an important role in the maturation and maintenance of synaptic function and connectivity. Indeed, genetic deletion of Trem2 leads to increased synaptic density and enhanced excitatory neurotransmission in the developing mouse hippocampus ${ }^{39}$, and mice expressing mutations in DAP12 display impaired synaptic maturation ${ }^{128}$. Emerging data further suggest a role for TREM2 in microglia-mediated synapse elimination. Culturing neurons with microglia from Trem2-deficient mice prevented synapse loss compared with microglia from wild-type mice ${ }^{79}$. Introducing the humanised $\mathrm{R} 47 \mathrm{H}$ variant of TREM2 into the TauP301S AD mouse model ameliorated $\mathrm{Clq}$ deposition on synapses and synaptic localisation within microglia compared with TauP301S mice with the TREM2 common variant ${ }^{11}$. A similar decrease of synaptic markers within microglial phagolysosomes was displayed in AD post-mortem human brains harbouring the $\mathrm{R} 47 \mathrm{H}$ and $\mathrm{R} 62 \mathrm{H}$ variants of TREM2 versus common variants ${ }^{11}$. This apparent neuroprotective role of the $\mathrm{R} 47 \mathrm{H}$ or $\mathrm{R} 62 \mathrm{H}$ variants, at first glance, does not concur with human genetics ${ }^{111,112}$. However, it may be in line with previous studies suggesting TREM2 as a critical immune sensor for damage and the $\mathrm{R} 47 \mathrm{H}$ variant impairing this ability to sense ${ }^{113}$. Akin to what has been shown for the role of classical complement cascade in $\mathrm{A} \beta$-induced synaptic loss versus plaque deposition ${ }^{6,8}$, whether TREM2 is beneficial versus detrimental may depend on the local milieu and the precise insult (that is, the identified 'damage' to be cleared $)^{129}$. Future studies, including behaviour and long-term effects on cognitive function, are needed to elucidate the roles of TREM2 in synaptic and cognitive health. Furthermore, whether ePtdSer or other damage-associated lipids contribute to TREM2-mediated synapse elimination in $\mathrm{AD}$ and whether this involves the complement reactivation in microglia are unclear.

\section{Astrocytic MFG-E8 as a potential phosphatidylserine} interactor

Astrocytes are intimately associated with synapses, physically ${ }^{130-133}$ and functionally ${ }^{134}$, where they maintain synaptic homeostasis ${ }^{135}$. They have been shown to mediate synapse formation and maturation ${ }^{136-139}$ as well as elimination ${ }^{40,41,140-142}$. Recent data in the developing visual thalamus suggest that astrocytes can mediate synapse loss by direct engulfment of synapses via MERTK and MEGF10 10,142 and by modulating microglial engulfment of synapses via secretion of IL-33 ${ }^{41}$. Interestingly, astrocytes in a given region are highly specialised to meet the demands of the neurons and synapses ${ }^{132}$. This raises the questions of whether and how astrocytes contribute to region-specific synapse vulnerability in disease.

In the peripheral immune system, MFG-E8 has been identified as a bifunctional molecular linker of apoptotic cells to phagocytes $^{143}$; that is, MFG-E8 binds simultaneously to ePtdSer 
and $\alpha 5 \beta 3$ or $\alpha 5 \beta 5$ receptors via a $\mathrm{C} 2$ domain and RGD motif, respectively ${ }^{144,145}$. In vitro, treating with annexin $\mathrm{V}$ or cyclical arginine-glycine-aspartic acid (cRGD) integrin-binding motif (which inhibit ePtdSer-MFG-E8 and MFG-E8-receptor interactions, respectively) prevents $\mathrm{A} \beta$-induced engulfment of neurons by microglia ${ }^{146,147}$. In vivo, genetic deletion of $M f g e 8$ reduces lipopolysaccharide-induced neuronal loss in the striatum $^{148}$. Furthermore, tau-laden neurons cultured from P301S-tau mice externalise PtdSer and subsequently are engulfed by microglia and this can be prevented by CRGD $^{149}$. Although these studies have focused on microglial MFG-E8, MFG-E8 appears to be enriched in astrocytes in the brain ${ }^{150-153}$, unlike in the periphery, where MFG-E8 is expressed by tissue-resident macrophages ${ }^{55,154,155}$. In Drosophila models, MFG-E8 is involved in the engulfment of dendrites, which display ePtdSer during developmental pruning or upon laser injury ${ }^{156}$. These data together raise the possibility of whether astrocytic MFG-E8 mediates cross-talk with microglia to facilitate synaptic engulfment.

\section{Potential cross-talk between microglia and astrocytes in mediating synaptosis}

Both microglia and astrocytes may be required for complement-mediated synapse loss. In the brain, microglia are a major cellular source of $\mathrm{C}_{1} \mathrm{q}^{6,157}$ and astrocytes are of $\mathrm{C} 3^{158}$. Microglia have been suggested to be responsible for the "conversion' of astrocytes to a reactive 'A1' phenotype, where C3 is a key marker, through a few factors, including $\mathrm{C}_{1} \mathrm{q}^{159}$. Furthermore, blocking this conversion appears neuroprotective in two models of neurodegenerative diseases: Parkinson's ${ }^{160}$ and amyotrophic lateral sclerosis ${ }^{161}$. However, whether astrocytic C3 is required for synapse loss in $\mathrm{AD}$ models needs to be further elucidated. Furthermore, microglia and astrocytes both are equipped with clearance machineries, raising the question of whether these two glia cell types have complementary or redundant roles in mediating synapse loss. For example, PtdSer receptors such as TAM receptor tyrosine kinases TYRO3, AXL and MER are expressed by both microglia and astrocytes ${ }^{40,55,150,158}$. Microglial TAM has been shown to mediate the clearance of apoptotic cells in the subgranular zone of the dentate gyrus and the subventricular zone, which are neurogenic regions in the adult central nervous system ${ }^{162}$. Time-lapse in vivo imaging showed microglia and astrocytes having distinct functions in the removal of single neurons that were dying upon two-photon ablation $^{163}$, such that microglia appeared to engulf large cell bodies while astrocytes engulf small diffuse debris. In vivo spinal cord imaging revealed an intimate physical interaction of astrocytes and microglia upon injury, and this interaction appears to require complement (C3) signalling ${ }^{164}$. Microglia were also suggested to instruct synaptic pruning by astrocytes in synaptic refinement, potentially via TREM $2^{165}$. Together, these data suggest that cross-talk between microglia and astrocytes have important functional consequences on synaptic health and neuronal function ${ }^{166}$.
In aged and $\mathrm{AD}$ brains, the transcriptional profiles of microglia and astrocytes are significantly altered ${ }^{120,153,158,167-171}$. In particular, microglia up-regulate PtdSer receptors such as Trem2 and $A x l^{120,167-170}$, and astrocytic expression of PtdSer-bridging molecules such as Pros1 and Mfge8 and receptors such as Megf10 becomes dysregulated ${ }^{149,153,158,172}$. Some intriguing questions are whether the changes of expression of these molecules involved in PtdSer recognition impair the ability of microglia or astrocytes to effectively respond to damaged synapses and neurons and whether they trigger the aberrant removal of otherwise healthy synapses.

\section{Conclusions}

Insight into molecular factors mediating region-specific synapse loss will be critical to changing the course of AD. Emerging data suggest that immune mechanisms involving classical complement cascade are critical for synaptic homeostasis, raising the key question of whether certain synapses are targeted for elimination by glia. To this end, recent literature highlights a potential role for ePtdSer in determining synaptic vulnerability. We postulate several pathways, including caspase-3 activation and mitochondrial dysfunction, that may lead to the externalisation of PtdSer on synapses (Figure 1). We then speculate how ePtdSer on synapses may be recognised by microglia or astrocytes (or both) for elimination (Figure 2). In particular, we focus on putative ePtdSer pathways such as TREM2 and MFG-E8. Altogether, we propose that synapses with ePtdSer may be selectively targeted by complement for deposition and subsequent engulfment by glia. However, to the best of our knowledge, no definitive link has been established between ePtdSer, complement and putative PtdSer receptors on glia. Furthermore, whether synaptic mitochondria become dysfunctional and contribute to synapse loss in $\mathrm{AD}$ needs further elucidation. As the classical complement cascade and microglia have been implicated in multiple models of neurologic diseases $^{36}$, understanding what makes synapses vulnerable to complement-mediated engulfment and loss will be crucial to resolving neuroimmune interactions critical for brain health.

Importantly, most of these mechanistic insights have been explored in rodent models, which can be a powerful tool to understanding the basic mechanisms of how our brain works. However, it is important to note that striking differences between mice and humans, especially in microglia ${ }^{170,173,174}$, may lead to fundamental differences in complex and chronic age-related neurodegenerative diseases such as AD. Additionally, in $\mathrm{A} \beta$-induced models of $\mathrm{AD}$, synapse loss has been suggested to precede overt plaque deposition ${ }^{6,175}$. However, in patients with $\mathrm{AD}$, when synapses start becoming vulnerable and lost is not fully understood. Recent development of imaging markers that selectively bind to synaptic elements ${ }^{22}$ will be instrumental in better defining the timeline progression of synaptic health in $\mathrm{AD}$. 


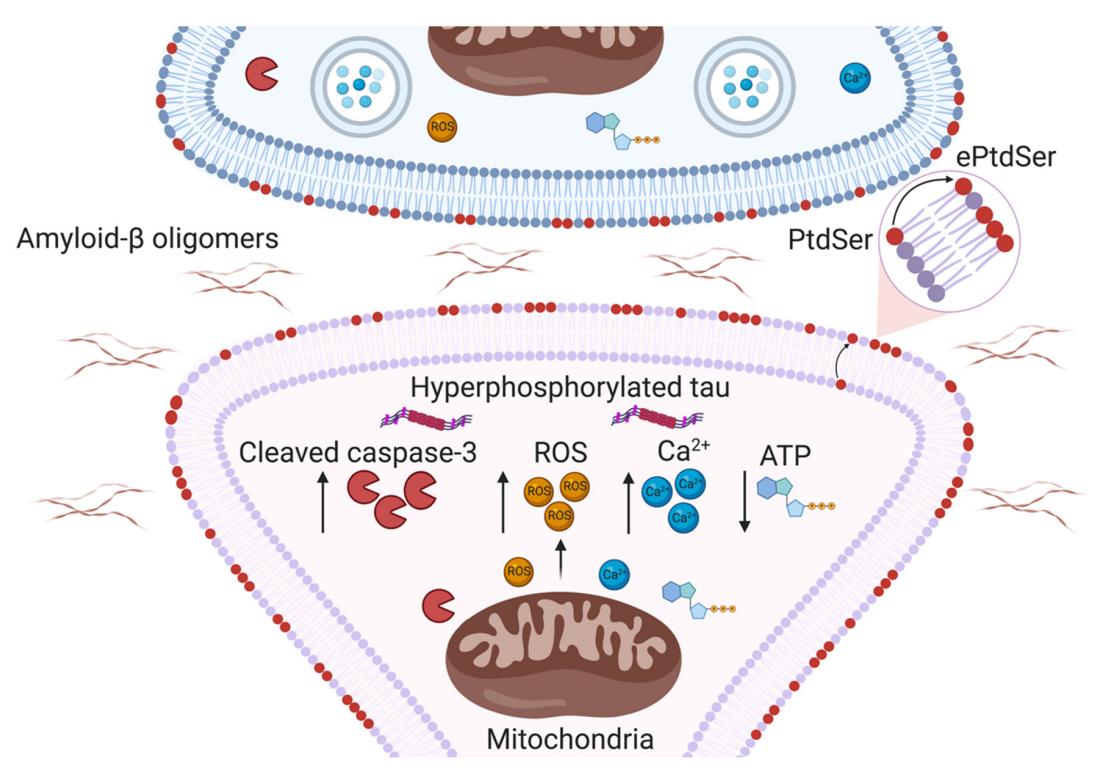

Figure 1. Potential mechanisms leading to synaptic phosphatidylserine externalisation in Alzheimer's disease. Schematic representation of potential pathways by which oligomeric amyloid-beta and hyperphosphorylated tau may increase the vulnerability of synapses to loss in Alzheimer's disease. Synaptic mitochondrial dysfunction may lead to a build-up of cleaved caspase-3, reactive oxygen species (ROS) and $\mathrm{Ca}^{2+}$, accompanied by a decrease in ATP. These events can modulate the activity of flippases and scramblases, enzymes which regulate the localisation of phosphatidylserine (PtdSer), such that PtdSer is locally externalised to the outer leaflet of synaptic membranes. ePtdSer, externalised phosphatidylserine.

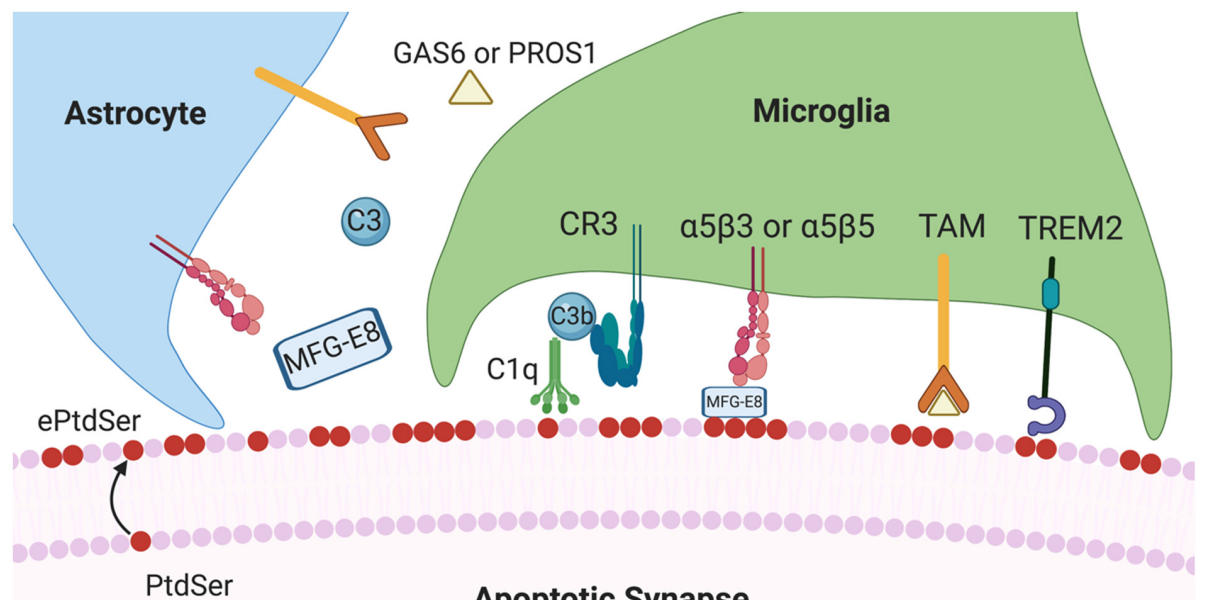

PtdSer

Apoptotic Synapse

Figure 2. Potential cross-talk between microglia and astrocytes in synapse elimination in Alzheimer's disease. Schematic representation of proposed glial mechanisms that may mediate the clearance of synapses upon potential externalisation of phosphatidylserine (PtdSer). C1a and C3 proteins secreted by neighbouring microglia and astrocytes, respectively, may mediate engulfment by microglia upon C3b-CR3 interaction. Triggering receptor expressed on myeloid cells 2 (TREM2) may be an important determinant of synapse loss, potentially via recognition of externalised phosphatidylserine (ePtdSer). Astrocytic milk fat globule-EGF factor 8 protein (MFG-E8) may facilitate the interaction between ePtdSer and $\alpha 5 \beta 3$ or $\alpha 5 \beta 5$ glial phagocytic receptors. Other putative glial PtdSer signalling pathways, such as GAS6/PROS1 and TAM (TYRO, AXL and MER) family of receptors, may also be involved in clearing of synapses with ePtdSer. 


\section{Acknowledgements}

We thank Morgan Sheng (Broad Institute, Cambridge, MA, USA), Cynthia Lemere (Brigham and Women's Hospital, Boston,
MA, USA) and Won-Suk Chung (KAIST, Daejeon, Republic of Korea) for critical reading of the manuscript. The figures were made with BioRender.
1. Bartels T, De Schepper S, Hong S: Microglia modulate neurodegeneration in Alzheimer's and Parkinson's diseases. Science. 2020; 370(6512): 66-9. PubMed Abstract | Publisher Full Text

2. Efthymiou AG, Goate AM: Late onset Alzheimer's disease genetics implicates microglial pathways in disease risk. Mol Neurodegener. 2017; 12(1): 43. PubMed Abstract | Publisher Full Text | Free Full Text

3. Sims R, van der Lee SJ, Naj AC, et al.: Rare coding variants in PLCG2, ABI3, and TREM2 implicate microglial-mediated innate immunity in Alzheimer's disease. Nat Genet. 2017; 49(9): 1373-84.

PubMed Abstract | Publisher Full Text | Free Full Text

4. Kunkle BW, Grenier-Boley B, Sims R, et al:: Genetic meta-analysis of diagnosed Alzheimer's disease identifies new risk loci and implicates A $\beta$, tau, immunity and lipid processing. Nat Genet. 2019; 51(3): 414-30. PubMed Abstract | Publisher Full Text | Free Full Text | Faculty Opinions Recommendation

5. Jansen IE, Savage JE, Watanabe K, et al.: Genome-wide meta-analysis identifies new loci and functional pathways influencing Alzheimer's disease risk. Nat Genet. 2019; 51(3): 404-13.

PubMed Abstract | Publisher Full Text | Free Full Text

6. Hong S, Beja-Glasser VF, Nfonoyim BM, et al:: Complement and microglia mediate early synapse loss in Alzheimer mouse models. Science. 2016 352(6286): 712-6.

PubMed Abstract | Publisher Full Text | Free Full Text |

Faculty Opinions Recommendation

7. Paolicelli RC, Jawaid A, Henstridge CM, et al.: TDP-43 Depletion in Microglia Promotes Amyloid Clearance but Also Induces Synapse Loss. Neuron. 2017; 95(2): 297-308.e6.

PubMed Abstract | Publisher Full Text | Free Full Text

8. Shi $\mathrm{Q}$, Chowdhury $\mathrm{S}, \mathrm{Ma} \mathrm{R}$, et al:: Complement $\mathrm{C} 3$ deficiency protects against neurodegeneration in aged plaque-rich APP/PS1 mice. Sci Transl Med. 2017 9(392): eaaf6295.

PubMed Abstract | Publisher Full Text | Free Full Tex

9. Dejanovic B, Huntley MA, de Mazière A, et al.: Changes in the Synaptic Proteome in Tauopathy and Rescue of Tau-Induced Synapse Loss by C1q Antibodies. Neuron. 2018; 100(6): 1322-1336.e7.

PubMed Abstract | Publisher Full Text | Faculty Opinions Recommendation

10. N Wu T, Dejanovic B, Gandham VD, et al:: Complement C3 Is Activated in Human AD Brain and Is Required for Neurodegeneration in Mouse Models of Amyloidosis and Tauopathy. Cell Rep. 2019; 28(8): 2111-2123.e6. PubMed Abstract | Publisher Full Text | Faculty Opinions Recommendation

11. C Gratuze M, Leyns CE, Sauerbeck AD, et al:: Impact of TREM2 ${ }^{\text {R47H }}$ variant on tau pathology-induced gliosis and neurodegeneration. J Clin Invest. 2020; 130(9): 4954-68.

PubMed Abstract | Publisher Full Text | Free Full Text |

Faculty Opinions Recommendation

12. Stevens B, Allen NJ, Vazquez LE, et al:: The classical complement cascade mediates CNS synapse elimination. Cell. 2007; 131(6): 1164-78. PubMed Abstract | Publisher Full Text | Faculty Opinions Recommendation

13. S Schafer DP, Lehrman EK, Kautzman AG, et al:: Microglia sculpt postnatal neural circuits in an activity and complement-dependent manner. Neuron. 2012; 74(4): 691-705.

PubMed Abstract | Publisher Full Text | Free Full Text | Faculty Opinions Recommendation

14. Mattson MP, Partin J, Begley JG: Amyloid beta-peptide induces apoptosisrelated events in synapses and dendrites. Brain Res. 1998; 807(1-2): 167-76. PubMed Abstract | Publisher Full Text

15. DD'Amelio M, Cavallucci V, Middei S, et al.: Caspase-3 triggers early synaptic dysfunction in a mouse model of Alzheimer's disease. Nat Neurosci. 2011 14(1): 69-76.

PubMed Abstract | Publisher Full Text | Faculty Opinions Recommendation

16. Park G, Nhan HS, Tyan SH, et al.: Caspase Activation and Caspase-Mediated
Cleavage of APP Is Associated with Amyloid $\beta$-Protein-Induced Synapse Loss in Alzheimer's Disease. Cell Rep. 2020; 31(13): 107839. PubMed Abstract | Publisher Full Text | Free Full Text

17. DeKosky ST, Scheff SW: Synapse loss in frontal cortex biopsies in Alzheimer's disease: Correlation with cognitive severity. Ann Neurol. 1990; 27(5): 457-64. PubMed Abstract | Publisher Full Text

18. Terry RD, Masliah E, Salmon DP, et al:: Physical basis of cognitive alterations in Alzheimer's disease: Synapse loss is the major correlate of cognitive impairment. Ann Neurol. 1991; 30(4): 572-80.

PubMed Abstract | Publisher Full Text

19. Scheff SW, Price DA, Schmitt FA, et al.: Hippocampal synaptic loss in early Alzheimer's disease and mild cognitive impairment. Neurobiol Aging. 2006; 27(10): 1372-84.

PubMed Abstract | Publisher Full Text

20. Scheff SW, Price DA, Schmitt FA, et al:: Synaptic alterations in CA1 in mild Alzheimer disease and mild cognitive impairment. Neurology. 2007; 68(18): 1501-8.

PubMed Abstract | Publisher Full Text

21. Scheff SW, Price DA, Schmitt FA, et al:: Synaptic loss in the inferior temporal gyrus in mild cognitive impairment and Alzheimer's disease. J Alzheimers Dis. 2011; 24(3): 547-57.

PubMed Abstract | Publisher Full Text | Free Full Text

22. Chen MK, Mecca AP, Naganawa M, et al:: Assessing Synaptic Density in Alzheimer Disease With Synaptic Vesicle Glycoprotein 2A Positron Emission Tomographic Imaging. JAMA Neurol. 2018; 75(10): 1215-24. PubMed Abstract | Publisher Full Text | Free Full Text

23. Fu H, Hardy J, Duff KE: Selective vulnerability in neurodegenerative diseases. Nat Neurosci. 2018; 21(10): 1350-8.

PubMed Abstract | Publisher Full Text | Free Full Text

24. Davies CA, Mann DM, Sumpter PQ, et al.: A quantitative morphometric analysis of the neuronal and synaptic content of the frontal and temporal cortex in patients with Alzheimer's disease. J Neurol Sci. 1987; 78(2): 151-64. PubMed Abstract | Publisher Full Text

25. Selkoe DJ: Alzheimer's disease is a synaptic failure. Science. 2002; 298(5594): 789-91.

PubMed Abstract | Publisher Full Text

26. Lambert MP, Barlow AK, Chromy BA, et al.: Diffusible, nonfibrillar ligands derived from Abeta $_{1-42}$ are potent central nervous system neurotoxins. Proc Natl Acad Sci U S A. 1998; 95(11): 6448-53.

PubMed Abstract | Publisher Full Text | Free Full Text

27. Walsh DM, Klyubin I, Fadeeva JV, et al:: Naturally secreted oligomers of amyloid beta protein potently inhibit hippocampal long-term potentiation in vivo. Nature. 2002; 416(6880): 535-9.

PubMed Abstract | Publisher Full Text | Faculty Opinions Recommendation

28. Spires TL, Meyer-Luehmann M, Stern EA, et al.: Dendritic spine abnormalities in amyloid precursor protein transgenic mice demonstrated by gene transfer and intravital multiphoton microscopy. J Neurosci. 2005; 25(31): 7278-87. PubMed Abstract | Publisher Full Text | Free Full Text

29. C Shankar GM, Bloodgood BL, Townsend M, et al.: Natural oligomers of the Alzheimer amyloid-beta protein induce reversible synapse loss by modulating an NMDA-type glutamate receptor-dependent signaling pathway. J Neurosci. 2007; 27(11): 2866-75.

PubMed Abstract | Publisher Full Text | Free Full Text | Faculty Opinions Recommendation

30. Shankar GM, Li S, Mehta TH, et al.: Amyloid-beta protein dimers isolated directly from Alzheimer's brains impair synaptic plasticity and memory. Nat Med. 2008; 14(8): 837-42.

PubMed Abstract | Publisher Full Text | Free Full Text | Faculty Opinions Recommendation

31. Koffie RM, Meyer-Luehmann M, Hashimoto T, et al.: Oligomeric amyloid beta associates with postsynaptic densities and correlates with excitatory synapse Ioss near senile plaques. Proc Natl Acad Sci U S A. 2009; 106(10): 4012-7. PubMed Abstract | Publisher Full Text | Free Full Text 
32. Zhou L, Mclnnes J, Wierda K, et al:: Tau association with synaptic vesicles causes presynaptic dysfunction. Nat Commun. 2017; 8: 15295. PubMed Abstract | Publisher Full Text | Free Full Text

33. Mclnnes J, Wierda K, Snellinx A, et al:: Synaptogyrin-3 Mediates Presynaptic Dysfunction Induced by Tau. Neuron. 2018; 97(4): 823-835.e8. PubMed Abstract | Publisher Full Text | Faculty Opinions Recommendation

34. Katz LC, Shatz CJ: Synaptic activity and the construction of cortical circuits. Science. 1996; 274(5290): 1133-8.

PubMed Abstract | Publisher Full Text

35. Neniskyte U, Gross CT: Errant gardeners: Glial-cell-dependent synaptic pruning and neurodevelopmental disorders. Nat Rev Neurosci. 2017; 18(11): 658-70.

PubMed Abstract | Publisher Full Text | Faculty Opinions Recommendation

36. de Schepper S, Crowley G, Hong S: Understanding microglial diversity and implications for neuronal function in health and disease. Dev Neurobiol. 2020. PubMed Abstract | Publisher Full Text

37. Paolicelli RC, Bolasco G, Pagani F, et al:: Synaptic pruning by microglia is necessary for normal brain development. Science. 2011; 333(6048): 1456-8. PubMed Abstract | Publisher Full Text | Faculty Opinions Recommendation

38. Zhan Y, Paolicelli RC, Sforazzini F, et al.: Deficient neuron-microglia signaling results in impaired functional brain connectivity and social behavior. Nat Neurosci. 2014; 17(3): 400-6.

PubMed Abstract | Publisher Full Text | Faculty Opinions Recommendation

39. Filipello F, Morini R, Corradini I, et al:: The Microglial Innate Immune Receptor TREM2 Is Required for Synapse Elimination and Normal Brain Connectivity. Immunity. 2018; 48(5): 979-991.e8.

PubMed Abstract | Publisher Full Tex

40. Chung WS, Clarke LE, Wang GX, et al.: Astrocytes mediate synapse elimination through MEGF10 and MERTK pathways. Nature. 2013; 504(7480): 394-400.

PubMed Abstract | Publisher Full Text | Free Full Text |

Faculty Opinions Recommendation

41. Vainchtein ID, Chin G, Cho FS, et al:: Astrocyte-derived interleukin-33 promotes microglial synapse engulfment and neural circuit development. Science. 2018; 359(6381): 1269-1273.

PubMed Abstract | Publisher Full Text | Free Full Text |

Faculty Opinions Recommendation

42. Huh GS, Boulanger LM, Du H, et al.: Functional requirement for class I MHC in CNS development and plasticity. Science. 2000; 290(5499): 2155-9. PubMed Abstract | Publisher Full Text | Free Full Text

43. Datwani A, McConnell MJ, Kanold PO, et al:: Classical MHCI molecules regulate retinogeniculate refinement and limit ocular dominance plasticity. Neuron. 2009; 64(4): 463-470.

PubMed Abstract | Publisher Full Text | Free Full Text

44. Kim T, Vidal GS, Djurisic M, et al.: Human LilrB2 is a $\beta$-amyloid receptor and its murine homolog PirB regulates synaptic plasticity in an Alzheimer's model. Science. 2013; 341(6152): 1399-404. PubMed Abstract | Publisher Full Text | Free Full Text

45. CLee H, Brott BK, Kirkby LA, et al.: Synapse elimination and learning rules co-regulated by MHC class I H2-Db. Nature. 2014; 509(7499): 195-200. PubMed Abstract | Publisher Full Text | Free Full Text | Faculty Opinions Recommendation

46. C Gunner G, Cheadle L, Johnson KM, et al.: Sensory lesioning induces microglial synapse elimination via ADAM10 and fractalkine signaling. Nat Neurosci. 2019; 22(7): 1075-1088.

PubMed Abstract | Publisher Full Text | Free Full Text |

Faculty Opinions Recommendation

47. Lui H, Zhang J, Makinson SR, et al:: Progranulin Deficiency Promotes Circuit-Specific Synaptic Pruning by Microglia via Complement Activation. Cell. 2016; 165(4): 921-35.

PubMed Abstract | Publisher Full Text | Free Full Text | Faculty Opinions Recommendation

48. Vasek MJ, Garber C, Dorsey D, et al.: A complement-microglial axis drives synapse loss during virus-induced memory impairment. Nature. 2016; 534(7608): 538-43.

PubMed Abstract | Publisher Full Text | Free Full Text |

Faculty Opinions Recommendation

49. Litvinchuk A, Wan Y-W, Swartzlander DB, et al.: Complement C3aR Inactivation Attenuates Tau Pathology and Reverses an Immune Network Deregulated in Tauopathy Models and Alzheimer's Disease. Neuron. 2018; 100(6): 1337-1353. e5.

PubMed Abstract | Publisher Full Text | Free Full Text

50. Vukojicic A, Delestrée N, Fletcher EV, et al:: The Classical Complement Pathway Mediates Microglia-Dependent Remodeling of Spinal Motor Circuits during Development and in SMA. Cell Rep. 2019; 29(10): 3087-3100. e7. PubMed Abstract | Publisher Full Text | Free Full Text

51. W Werneburg S, Jung J, Kunjamma RB, et al.: Targeted Complement Inhibition at Synapses Prevents Microglial Synaptic Engulfment and Synapse Loss in
Demyelinating Disease. Immunity. 2020; 52(1): 167-182. e7. PubMed Abstract | Publisher Full Text | Free Full Text | Faculty Opinions Recommendation

52. Mevorach D, Mascarenhas JO, Gershov D, et al.: Complement-dependent clearance of apoptotic cells by human macrophages. J Exp Med. 1998; 188(12): 2313-20.

PubMed Abstract | Publisher Full Text | Free Full Text

53. Gasque P: Complement: A unique innate immune sensor for danger signals. Mol Immunol. 2004; 41(11): 1089-98.

PubMed Abstract | Publisher Full Text

54. Martin $\mathrm{M}$, Leffler J, Smoląg KI, et al.: Factor $\mathbf{H}$ uptake regulates intracellular C3 activation during apoptosis and decreases the inflammatory potential of nucleosomes. Cell Death Differ. 2016; 23(5): 903-11. PubMed Abstract | Publisher Full Text | Free Full Text

55. Lemke G: How macrophages deal with death. Nat Rev Immunol. 2019; 19(9): 539-49.

PubMed Abstract | Publisher Full Text | Free Full Text

56. Ricklin D, Hajishengallis G, Yang K, et al.: Complement: A key system for immune surveillance and homeostasis. Nat Immunol. 2010; 11(9): 785-97. PubMed Abstract | Publisher Full Text | Free Full Text

57. Stephan AH, Madison DV, Mateos JM, et al:: A dramatic increase of C1q protein in the CNS during normal aging. $J$ Neurosci. 2013; 33(33): 13460-74. PubMed Abstract | Publisher Full Text | Free Full Text

58. Chu Y, Jin X, Parada I, et al.: Enhanced synaptic connectivity and epilepsy in C1q knockout mice. Proc Natl Acad Sci U S A. 2010; 107(17): 7975-80. PubMed Abstract | Publisher Full Text | Free Full Text | Faculty Opinions Recommendation

59. Perez-Alcazar M, Daborg J, Stokowska A, et al.: Altered cognitive performance and synaptic function in the hippocampus of mice lacking C3. Exp Neurol. 2014; 253: 154-64. PubMed Abstract | Publisher Full Text

60. Wang $\mathrm{C}$, Yue $\mathrm{H}, \mathrm{Hu} \mathrm{Z}$, et al.: Microglia mediate forgetting via complementdependent synaptic elimination. Science. 2020; 367(6478): 688-694. PubMed Abstract | Publisher Full Text | Faculty Opinions Recommendation

61. Morrison JH, Baxter MG: The ageing cortical synapse: Hallmarks and implications for cognitive decline. Nat Rev Neurosci. 2012; 13(4): 240-50. PubMed Abstract | Publisher Full Text | Free Full Text

62. Shi Q, Colodner KJ, Matousek SB, et al.: Complement C3-Deficient Mice Fail to Display Age-Related Hippocampal Decline. J Neurosci. 2015; 35(38): 13029-42. PubMed Abstract | Publisher Full Text | Free Full Text

63. Wyss-Coray T, Rogers J: Inflammation in Alzheimer disease-a brief review of the basic science and clinical literature. Cold Spring Harb Perspect Med. 2012; 2(1): a006346.

PubMed Abstract | Publisher Full Text | Free Full Text

64. Eikelenboom P, Stam FC: Immunoglobulins and complement factors in senile plaques. An immunoperoxidase study. Acta Neuropathol. 1982; 57(2-3): 239-42. PubMed Abstract | Publisher Full Text

65. Morgan BP: Complement in the pathogenesis of Alzheimer's disease. Semin Immunopathol. 2018; 40(1): 113-124. PubMed Abstract | Publisher Full Text | Free Full Text

66. Lambert J-C, Heath S, Even G, et al:: Genome-wide association study identifies variants at CLU and CR1 associated with Alzheimer's disease. Nat Genet. 2009; 41(10): 1094-9.

PubMed Abstract | Publisher Full Text

67. Fonseca MI, Zhou J, Botto M, et al:: Absence of C1q leads to less neuropathology in transgenic mouse models of Alzheimer's disease. J Neurosci. 2004; 24(29): 6457-65

PubMed Abstract | Publisher Full Text | Free Full Text

68. Wyss-Coray T, Yan F, Lin AH-T, et al.: Prominent neurodegeneration and increased plaque formation in complement-inhibited Alzheimer's mice. Proc Natl Acad Sci U S A. 2002; 99(16): 10837-42. PubMed Abstract | Publisher Full Text | Free Full Text

69. Maier $\mathrm{M}$, Peng $\mathrm{Y}$, Jiang $\mathrm{L}$, et al.: Complement $\mathrm{C} 3$ deficiency leads to accelerated amyloid beta plaque deposition and neurodegeneration and modulation of the microglia/macrophage phenotype in amyloid precursor protein transgenic mice. J Neurosci. 2008; 28(25): 6333-41. PubMed Abstract | Publisher Full Text | Free Full Text

70. Jo J, Whitcomb DJ, Olsen KM, et al:: Aß(1-42) inhibition of LTP is mediated by a signaling pathway involving caspase-3, Akt1 and GSK-3ß. Nat Neurosci. 2011; 14(5): 545-7.

PubMed Abstract | Publisher Full Text

71. Ertürk $A$, Wang $Y$, Sheng M: Local pruning of dendrites and spines by caspase-3-dependent and proteasome-limited mechanisms. J Neurosci. 2014; 34(5): 1672-88.

PubMed Abstract | Publisher Full Text | Free Full Text

72. Louneva N, Cohen JW, Han L-Y, et al:: Caspase-3 is enriched in postsynaptic densities and increased in Alzheimer's disease. Am J Pathol. 2008; 173(5): 1488-95.

PubMed Abstract | Publisher Full Text | Free Full Text |

Faculty Opinions Recommendation 
73. Sheng M, Ertürk A: Long-term depression: A cell biological view. Philos Trans $R$ Soc Lond B Biol Sci. 2014; 369(1633): 20130138.

PubMed Abstract | Publisher Full Text | Free Full Text

74. Mattson MP, Keller JN, Begley JG: Evidence for synaptic apoptosis. Exp Neurol. 1998; 153(1): 35-48.

PubMed Abstract | Publisher Full Text

75. C Suzuki J, Denning DP, Imanishi E, et al:: Xk-related protein 8 and CED-8 promote phosphatidylserine exposure in apoptotic cells. Science. 2013 341(6144): 403-6.

PubMed Abstract | Publisher Full Text | Faculty Opinions Recommendation

76. Suzuki J, Imanishi E, Nagata S: Exposure of phosphatidylserine by Xk-related protein family members during apoptosis. J Biol Chem. 2014; 289(44): 30257-67.

PubMed Abstract | Publisher Full Text | Free Full Text

77. C Segawa K, Kurata S, Yanagihashi Y, et al.: Caspase-mediated cleavage of phospholipid flippase for apoptotic phosphatidylserine exposure. Science. 2014; 344(6188): 1164-8.

PubMed Abstract | Publisher Full Text | Faculty Opinions Recommendation

78. Païdassi H, Tacnet-Delorme P, Garlatti V, et al.: C1q binds phosphatidylserine and likely acts as a multiligand-bridging molecule in apoptotic cell recognition. J Immunol. 2008; 180(4): 2329-38. PubMed Abstract | Publisher Full Text | Free Full Text

79. Scott-Hewitt N, Perrucci F, Morini R, et al:: Local externalization of phosphatidylserine mediates developmental synaptic pruning by microglia. EMBO J. 2020; 39(16): e105380.

PubMed Abstract | Publisher Full Text | Free Full Text

80. Li T, Chiou B, Gilman CK, et al:: A splicing isoform of GPR56 mediates microglial synaptic refinement via phosphatidylserine binding. EMBO J.2020 39(16): e104136.

PubMed Abstract | Publisher Full Text | Free Full Text

81. Riedl SJ, Salvesen GS: The apoptosome: Signalling platform of cell death. Nat Rev Mol Cell Biol. 2007; 8(5): 405-13.

PubMed Abstract | Publisher Full Tex

82. Shacham-Silverberg V, Shalom HS, Goldner R, et al:: Phosphatidylserine is a marker for axonal debris engulfment but its exposure can be decoupled from degeneration. Cell Death Dis. 2018; 9(11): 1116

PubMed Abstract | Publisher Full Text | Free Full Text

83. Terni B, Boada J, Portero-Otin M, et al:: Mitochondrial ATP-synthase in the entorhinal cortex is a target of oxidative stress at stages $\mathrm{I} / \mathrm{Il}$ of Alzheimer's disease pathology. Brain Pathol. 2010; 20(1): 222-33. PubMed Abstract | Publisher Full Text

84. Cha MY, Cho HJ, Kim C, et al:: Mitochondrial ATP synthase activity is impaired by suppressed O-GIcNAcylation in Alzheimer's disease. Hum Mol Genet. 2015 24(22): 6492-504.

PubMed Abstract | Publisher Full Text | Free Full Text

85. Beck SJ, Guo L, Phensy A, et al:: Deregulation of mitochondrial F1FO-ATP synthase via OSCP in Alzheimer's disease. Nat Commun. 2016; 7: 11483. PubMed Abstract | Publisher Full Text | Free Full Text

86. Hesse R, Hurtado ML, Jackson RJ, et al:: Comparative profiling of the synaptic proteome from Alzheimer's disease patients with focus on the APOE genotype. Acta Neuropathol Commun. 2019; 7(1): 214. PubMed Abstract | Publisher Full Text | Free Full Text

87. Györffy BA, Tóth V, Török G, et al.: Synaptic mitochondrial dysfunction and septin accumulation are linked to complement-mediated synapse loss in an Alzheimer's disease animal model. Cell Mol Life Sci. 2020; 77(24): 5243-5258. PubMed Abstract | Publisher Full Text | Free Full Text

88. Sorrentino V, Romani M, Mouchiroud L: Enhancing mitochondrial proteostasis reduces amyloid- $\beta$ proteotoxicity. Nature. 2017; 552(7684): 187-193.

PubMed Abstract | Publisher Full Text | Free Full Text | Faculty Opinions Recommendation

89. Zachowski A, Henry JP, Devaux PF: Control of transmembrane lipid asymmetry in chromaffin granules by an ATP-dependent protein. Nature. 1989; 340(6228): 75-6.

PubMed Abstract | Publisher Full Text

90. Tang X, Halleck MS, Schlegel RA, et al:: A subfamily of P-type ATPases with aminophospholipid transporting activity. Science. 1996; 272(5267): 1495-7. PubMed Abstract | Publisher Full Text

91. N Yabas M, Teh CE, Frankenreiter S, et al:: ATP11C is critical for the internalization of phosphatidylserine and differentiation of $B$ lymphocytes. Nat Immunol. 2011; 12(5): 441-9.

PubMed Abstract | Publisher Full Text | Free Full Text | Faculty Opinions Recommendation

92. Segawa K, Kurata S, Nagata S: Human Type IV P-type ATPases That Work as Plasma Membrane Phospholipid Flippases and Their Regulation by Caspase and Calcium. J Biol Chem. 2016; 291(2): 762-72.

PubMed Abstract | Publisher Full Text | Free Full Text

93. Schreiber R, Ousingsawat J, Wanitchakool P, et al.: Regulation of TMEM16A/ ANO1 and TMEM16F/ANO6 ion currents and phospholipid scrambling by $\mathrm{Ca}^{2+}$ and plasma membrane lipid. J Physiol. 2018; 596(2): 217-229. PubMed Abstract | Publisher Full Text | Free Full Tex
94. Suzuki J, Umeda M, Sims PJ, et al:: Calcium-dependent phospholipid scrambling by TMEM16F. Nature. 2010; 468(7325): 834-8.

PubMed Abstract | Publisher Full Text | Faculty Opinions Recommendation

95. Suzuki J, Fujii T, Imao T, et al: Calcium-dependent phospholipid scramblase activity of TMEM16 protein family members. J Biol Chem. 2013; 288(19): 13305-16.

PubMed Abstract | Publisher Full Text | Free Full Text

96. Zorov DB, Juhaszova M, Sollott SJ: Mitochondrial reactive oxygen species (ROS) and ROS-induced ROS release. Physiol Rev. 2014; 94(3): 909-50. PubMed Abstract | Publisher Full Text | Free Full Text

97. Devine MJ, Kittler JT: Mitochondria at the neuronal presynapse in health and disease. Nat Rev Neurosci. 2018; 19(2): 63-80.

PubMed Abstract | Publisher Full Text

98. Pivovarova NB, Pozzo-Miller LD, Hongpaisan J, et al.: Correlated Calcium Uptake and Release by Mitochondria and Endoplasmic Reticulum of CA3 Hippocampal Dendrites after Afferent Synaptic Stimulation. J Neurosci. 2002; 22(24): 10653-61.

PubMed Abstract | Publisher Full Text | Free Full Text

99. Billups B, Forsythe ID: Presynaptic Mitochondrial Calcium Sequestration Influences Transmission at Mammalian Central Synapses. J Neurosci. 2002; 22(14): 5840-7

PubMed Abstract | Publisher Full Text | Free Full Text

100. Calvo-Rodriguez M, Hou SS, Snyder AC, et al:: Increased mitochondrial calcium levels associated with neuronal death in a mouse model of Alzheimer's disease. Nat Commun. 2020; 11(1): 2146. PubMed Abstract | Publisher Full Text | Free Full Text

101. Du H, Guo L, Fang F, et al.: Cyclophilin D deficiency attenuates mitochondrial and neuronal perturbation and ameliorates learning and memory in Alzheimer's disease. Nat Med. 2008; 14(10): 1097-105. PubMed Abstract | Publisher Full Text | Free Full Text | Faculty Opinions Recommendation

102. Lee SH, Kim KR, Ryu SY, et al.: Impaired short-term plasticity in mossy fiber synapses caused by mitochondrial dysfunction of dentate granule cells is the earliest synaptic deficit in a mouse model of Alzheimer's disease. J Neurosci. 2012; 32(17): 5953-63.

PubMed Abstract | Publisher Full Text | Free Full Text

103. Du H, Guo L, Yan S, et al.: Early deficits in synaptic mitochondria in an Alzheimer's disease mouse model. Proc Natl Acad Sci U S A. 2010; 107(43): 18670-5.

PubMed Abstract | Publisher Full Text | Free Full Text

104. Ahmad F, Singh K, Das D, et al.: Reactive Oxygen Species-Mediated Loss of Synaptic Akt1 Signaling Leads to Deficient Activity-Dependent Protein Translation Early in Alzheimer's Disease. Antioxid Redox Signal. 2017; 27(16): 1269-1280.

PubMed Abstract | Publisher Full Text | Free Full Text

105. Rothlin CV, Carrera-Silva EA, Bosurgi L, et al.: TAM receptor signaling in immune homeostasis. Annu Rev Immunol. 2015; 33: 355-91. PubMed Abstract | Publisher Full Text | Free Full Text

106. Takahashi K, Rochford CDP, Neumann H: Clearance of apoptotic neurons without inflammation by microglial triggering receptor expressed on myeloid cells-2. J Exp Med. 2005; 201(4): 647-57.

PubMed Abstract | Publisher Full Text | Free Full Text Faculty Opinions Recommendation

107. Hsieh CL, Koike M, Spusta SC, et al.: A role for TREM2 ligands in the phagocytosis of apoptotic neuronal cells by microglia. J Neurochem. 2009; 109(4): 1144-56.

PubMed Abstract | Publisher Full Text | Free Full Text

108. Shirotani K, Hori Y, Yoshizaki R, et al:: Aminophospholipids are signaltransducing TREM2 ligands on apoptotic cells. Sci Rep. 2019; 9(1): 7508 PubMed Abstract | Publisher Full Text | Free Full Text

109. Deczkowska A, Weiner A, Amit I: The Physiology, Pathology, and Potential Therapeutic Applications of the TREM2 Signaling Pathway. Cell. 2020; 181(6): 1207-1217.

PubMed Abstract | Publisher Full Text | Faculty Opinions Recommendation

110. Sudom A, Talreja S, Danao J, et al:: Molecular basis for the loss-of-function effects of the Alzheimer's disease-associated R47H variant of the immune receptor TREM2. J Biol Chem. 2018; 293(32): 12634-12646. PubMed Abstract | Publisher Full Text | Free Full Text | Faculty Opinions Recommendation

111. C Guerreiro R, Wojtas A, Bras J, et al.: TREM2 variants in Alzheimer's disease. N Engl J Med. 2013; 368(2): 117-27. PubMed Abstract | Publisher Full Text | Free Full Text | Faculty Opinions Recommendation

112. Jonsson T, Stefansson H, Steinberg S, et al.: Variant of TREM2 associated with the risk of Alzheimer's disease. N Engl J Med. 2013; 368(2): 107-16. PubMed Abstract | Publisher Full Text | Free Full Text | Faculty Opinions Recommendation

113. Deczkowska A, Keren-Shaul H, Weiner A, et al:: Disease-Associated Microglia: A Universal Immune Sensor of Neurodegeneration. Cell. 2018; 
173(5): 1073-1081

PubMed Abstract | Publisher Full Text | Faculty Opinions Recommendation

114. W Wang Y, Cella M, Mallinson K, et al.: TREM2 lipid sensing sustains the microglial response in an Alzheimer's disease model. Cell. 2015; 160(6): 1061-71.

PubMed Abstract | Publisher Full Text | Free Full Text | Faculty Opinions Recommendation

115. Ulland TK, Song WM, Huang SCC, et al.: TREM2 Maintains Microglial Metabolic Fitness in Alzheimer's Disease. Cell. 2017; 170(4): 649-663.e13. PubMed Abstract | Publisher Full Text | Free Full Text

116. Ulrich JD, Finn MB, Wang $Y$, et al:: Altered microglial response to $\mathbf{A} \boldsymbol{\beta}$ plaques in APPPS1-21 mice heterozygous for TREM2. Mol Neurodegener. 2014; 9: 20 PubMed Abstract | Publisher Full Text | Free Full Text

117. Jay TR, Miller CM, Cheng PJ, et al:: TREM2 deficiency eliminates TREM2+ inflammatory macrophages and ameliorates pathology in Alzheimer's disease mouse models. J Exp Med. 2015; 212(3): 287-95. PubMed Abstract | Publisher Full Text | Free Full Text

118. Wang $Y$, Ulland TK, Ulrich JD, et al:: TREM2-mediated early microglial response limits diffusion and toxicity of amyloid plaques. J Exp Med. 2016; 213(5): 667-75. PubMed Abstract | Publisher Full Text | Free Full Text

119. CYuan P, Condello C, Keene CD, et al.: TREM2 Haplodeficiency in Mice and Humans Impairs the Microglia Barrier Function Leading to Decreased Amyloid Compaction and Severe Axonal Dystrophy. Neuron. 2016; 90(4): 724-39. PubMed Abstract | Publisher Full Text | Free Full Text | Faculty Opinions Recommendation

120. Keren-Shaul H, Spinrad A, Weiner A, et al.: A Unique Microglia Type Associated with Restricting Development of Alzheimer's Disease. Cell. 2017; 169(7): 1276-1290.e17.

PubMed Abstract | Publisher Full Text | Faculty Opinions Recommendation

121. Nugent AA, Lin $\mathrm{K}$, van Lengerich $\mathrm{B}$, et al:: TREM2 Regulates Microglial Cholesterol Metabolism upon Chronic Phagocytic Challenge. Neuron. 2020; 105(5): 837-854.e9.

PubMed Abstract | Publisher Full Text

122. CPiers TM, Cosker K, Mallach A, et al.: A locked immunometabolic switch underlies TREM2 R47H loss of function in human iPSC-derived microglia. FASEB J. 2020; 34(2): 2436-2450.

PubMed Abstract | Publisher Full Text | Free Full Text | Faculty Opinions Recommendation

123. Zhou Y, Song WM, Andhey PS, et al:: Human and mouse single-nucleus transcriptomics reveal TREM2-dependent and TREM2-independent cellula responses in Alzheimer's disease. Nat Med. 2020; 26(1): 131-142. PubMed Abstract | Publisher Full Text | Free Full Text

124. Hall-Roberts H, Agarwal D, Obst J, et al:: TREM2 Alzheimer's variant R47H causes similar transcriptional dysregulation to knockout, yet only subtle functional phenotypes in human iPSC-derived macrophages. Alzheimers Res Ther. 2020; 12(1): 151.

PubMed Abstract | Publisher Full Text | Free Full Text

125. Marschallinger J, Iram T, Zardeneta M, et al.: Lipid-droplet-accumulating microglia represent a dysfunctional and proinflammatory state in the aging brain. Nat Neurosci. 2020; 23(2): 194-208.

PubMed Abstract | Publisher Full Text | Free Full Text | Faculty Opinions Recommendation

126. Paloneva J, Kestilä M, Wu J, et al.: Loss-of-function mutations in TYROBP (DAP12) result in a presenile dementia with bone cysts. Nat Genet. 2000; 25(3): $357-61$.

PubMed Abstract | Publisher Full Text

127. Paloneva J, Manninen T, Christman G, et al:: Mutations in two genes encoding different subunits of a receptor signaling complex result in an identical disease phenotype. Am J Hum Genet. 2002; 71(3): 656-62. PubMed Abstract | Publisher Full Text | Free Full Text

128. Roumier A, Béchade C, Poncer JC, et al.: Impaired synaptic function in the microglial KARAP/DAP12-deficient mouse. J Neurosci. 2004; 24(50): 11421-8. PubMed Abstract | Publisher Full Text | Free Full Text | Faculty Opinions Recommendation

129. Rueda-Carrasco J, Hong S: The Jekyll and Hyde of TREM2. Trends Neurosci. 2020; 43(10): 739-740. PubMed Abstract | Publisher Full Text

130. Haber M, Zhou L, Murai KK: Cooperative astrocyte and dendritic spine dynamics at hippocampal excitatory synapses. J Neurosci. 2006; 26(35): 8881-91.

PubMed Abstract | Publisher Full Text | Free Full Text | Faculty Opinions Recommendation

131. Halassa MM, Fellin $\mathrm{T}$, Takano $\mathrm{H}$, et al:: Synaptic islands defined by the territory of a single astrocyte. J Neurosci. 2007; 27(24): 6473-7. PubMed Abstract | Publisher Full Text | Free Full Tex

132. C Chai H, Diaz-Castro B, Shigetomi E, et al:: Neural Circuit-Specialized Astrocytes: Transcriptomic, Proteomic, Morphological, and Functional
Evidence. Neuron. 2017; 95(3): 531-549.e9.

PubMed Abstract | Publisher Full Text | Free Full Text |

Faculty Opinions Recommendation

133. Octeau JC, Chai H, Jiang R, et al:: An Optical Neuron-Astrocyte Proximity Assay at Synaptic Distance Scales. Neuron. 2018; 98(1): 49-66.e9. PubMed Abstract | Publisher Full Text | Free Full Text | Faculty Opinions Recommendation

134. Haydon PG, Nedergaard M: How do astrocytes participate in neural plasticity? Cold Spring Harb Perspect Biol. 2014; 7(3): a020438. PubMed Abstract | Publisher Full Text | Free Full Text

135. Araque A, Parpura V, Sanzgiri RP, et al.: Tripartite synapses: Glia, the unacknowledged partner. Trends Neurosci. 1999; 22(5): 208-15. PubMed Abstract | Publisher Full Text

136. Eroglu C: The role of astrocyte-secreted matricellular proteins in central nervous system development and function. J Cell Commun Signal. 2009; 3(3-4): $167-76$.

PubMed Abstract | Publisher Full Text | Free Full Text

137. Allen NJ, Bennett ML, Foo LC, et al.: Astrocyte glypicans 4 and 6 promote formation of excitatory synapses via GluA1 AMPA receptors. Nature. 2012; 486(7403): 410-4.

PubMed Abstract | Publisher Full Text | Free Full Text | Faculty Opinions Recommendation

138. Allen NJ, Eroglu C: Cell Biology of Astrocyte-Synapse Interactions. Neuron. 2017; 96(3): 697-708. PubMed Abstract | Publisher Full Text | Free Full Text Faculty Opinions Recommendation

139. Farhy-Tselnicker I, van Casteren ACM, Lee A, et al:: Astrocyte-Secreted Glypican 4 Regulates Release of Neuronal Pentraxin 1 from Axons to Induce Functional Synapse Formation. Neuron. 2017; 96(2): 428-445.e13. PubMed Abstract | Publisher Full Text | Free Full Text

140. Tasdemir-Yilmaz OE, Freeman MR: Astrocytes engage unique molecular programs to engulf pruned neuronal debris from distinct subsets of neurons. Genes Dev. 2014; 28(1): 20-33.

PubMed Abstract | Publisher Full Text | Free Full Text

141. Chung WS, Allen NJ, Eroglu C: Astrocytes Control Synapse Formation, Function, and Elimination. Cold Spring Harb Perspect Biol. 2015; 7(9): a020370. PubMed Abstract | Publisher Full Text | Free Full Text

142. Chung WS, Verghese PB, Chakraborty C, et al.: Novel allele-dependent role for APOE in controlling the rate of synapse pruning by astrocytes. Proc Natl Acad Sci U S A. 2016; 113(36): 10186-91. PubMed Abstract | Publisher Full Text | Free Full Text

143. Hanayama R, Tanaka M, Miwa K, et al.: Identification of a factor that links apoptotic cells to phagocytes. Nature. 2002; 417(6885): 182-7. PubMed Abstract | Publisher Full Text | Faculty Opinions Recommendation

144. $\mathrm{Ye} \mathrm{H}, \mathrm{Li} \mathrm{B}$, Subramanian $\mathrm{V}$, et al:: NMR solution structure of $\mathbf{C 2}$ domain of MFG-E8 and insights into its molecular recognition with phosphatidylserine. Biochim Biophys Acta. 2013; 1828(3): 1083-93. PubMed Abstract | Publisher Full Text

145. Castellanos ER, Ciferri C, Phung W, et al.: Expression, purification, and characterization of recombinant human and murine milk fat globule-epidermal growth factor-factor 8. Protein Expr Purif. 2016; 124: 10-22. PubMed Abstract | Publisher Full Text

146. Neniskyte U, Neher JJ, Brown GC: Neuronal death induced by nanomolar amyloid $\beta$ is mediated by primary phagocytosis of neurons by microglia. $J$ Biol Chem. 2011; 286(46): 39904-13

PubMed Abstract | Publisher Full Text | Free Full Text

147. Neniskyte U, Brown GC: Lactadherin/MFG-E8 is essential for microgliamediated neuronal loss and phagoptosis induced by amyloid $\beta$. J Neurochem 2013; 126(3): 312-7. PubMed Abstract | Publisher Full Text

148. Fricker M, Oliva-Martín MJ, Brown GC: Primary phagocytosis of viable neurons by microglia activated with LPS or A $\beta$ is dependent on calreticulin/LRP phagocytic signalling. $J$ Neuroinflammation. 2012; 9: 196. PubMed Abstract | Publisher Full Text | Free Full Text

149. Brelstaff J, Tolkovsky AM, Ghetti B, et al:: Living Neurons with Tau Filaments Aberrantly Expose Phosphatidylserine and Are Phagocytosed by Microglia. Cell Rep. 2018; 24(8): 1939-1948.e4. PubMed Abstract | Publisher Full Text | Free Full Text

150. C Cahoy JD, Emery B, Kaushal A, et al.: A transcriptome database for astrocytes, neurons, and oligodendrocytes: A new resource for understanding brain development and function. J Neurosci. 2008; 28(1): 264-78. PubMed Abstract | Publisher Full Text | Free Full Text | Faculty Opinions Recommendation

151. Zeisel A, Muñoz-Manchado AB, Codeluppi S, et al:: Brain structure. Cell types in the mouse cortex and hippocampus revealed by single-cell RNA-seq. Science. 2015; 347(6226): 1138-42.

PubMed Abstract | Publisher Full Text | Faculty Opinions Recommendation

152. Zeisel $\mathrm{A}$, Hochgerner $\mathrm{H}$, Lönnerberg $\mathrm{P}$, et al: Molecular Architecture of the 
Mouse Nervous System. Cell. 2018; 174(4): 999-1014.e22. PubMed Abstract | Publisher Full Text | Free Full Text

153. Habib N, McCabe C, Medina S, et al:: Disease-associated astrocytes in Alzheimer's disease and aging. Nat Neurosci. 2020; 23(6): 701-6. PubMed Abstract | Publisher Full Text

154. Hanayama R, Tanaka M, Miyasaka K, et al.: Autoimmune disease and impaired uptake of apoptotic cells in MFG-E8-deficient mice. Science. 2004 304(5674): 1147-50. PubMed Abstract | Publisher Full Text | Faculty Opinions Recommendation

155. N Miyanishi M, Tada K, Koike M, et al:: Identification of Tim4 as a phosphatidylserine receptor. Nature. 2007; 450(7168): 435-9. PubMed Abstract | Publisher Full Text | Faculty Opinions Recommendation

156. Sapar ML, Ji H, Wang B, et al:: Phosphatidylserine Externalization Results from and Causes Neurite Degeneration in Drosophila. Cell Rep. 2018; 24(9): 2273-86. PubMed Abstract | Publisher Full Text | Free Full Text

157. Fonseca MI, Chu SH, Hernandez MX, et al.: Cell-specific deletion of C1qa identifies microglia as the dominant source of $\mathrm{C} 1 \mathrm{q}$ in mouse brain. J Neuroinflammation. 2017; 14(1): 48. PubMed Abstract | Publisher Full Text | Free Full Text

158. Clarke LE, Liddelow SA, Chakraborty C, et al.: Normal aging induces A1-like astrocyte reactivity. Proc Natl Acad Sci U S A. 2018; 115(8): E1896-E1905. PubMed Abstract | Publisher Full Text | Free Full Text | Faculty Opinions Recommendation

159. Liddelow SA, Guttenplan KA, Clarke LE, et al:: Neurotoxic reactive astrocytes are induced by activated microglia. Nature. 2017; 541(7638): 481-7. PubMed Abstract | Publisher Full Text | Free Full Text | Faculty Opinions Recommendation

160. Yun SP, Kam TI, Panicker N, et al.: Block of A1 astrocyte conversion by microglia is neuroprotective in models of Parkinson's disease. Nat Med. 2018; 24(7): 931-8.

PubMed Abstract | Publisher Full Text | Free Full Tex

161. Guttenplan KA, Weigel MK, Adler DI, et al: Knockout of reactive astrocyte activating factors slows disease progression in an ALS mouse model. Nat Commun. 2020; 11(1): 3753.

PubMed Abstract | Publisher Full Text | Free Full Text

162. Fourgeaud $L$, Través $P G$, Tufail $Y$, et al.: TAM receptors regulate multiple features of microglial physiology. Nature. 2016; 532(7598): 240-4. PubMed Abstract | Publisher Full Text | Free Full Text

163. Damisah EC, Hill RA, Rai A, et al:: Astrocytes and microglia play orchestrated roles and respect phagocytic territories during neuronal corpse removal in vivo. Sci Adv. 2020; 6(26): eaba3239. PubMed Abstract | Publisher Full Text | Free Full Text

164. Chen T, Lennon VA, Liu YU, et al:: Astrocyte-microglia interaction drives evolving neuromyelitis optica lesion. J Clin Invest. 2020; 130(8): 4025-38. PubMed Abstract | Publisher Full Text | Free Full Text
165. Jay TR, von Saucken VE, Muñoz B, et al:: TREM2 is required for microglial instruction of astrocytic synaptic engulfment in neurodevelopment. Glia. 2019; 67(10): 1873-92.

PubMed Abstract | Publisher Full Text

166. Matejuk A, Ransohoff RM: Crosstalk Between Astrocytes and Microglia: An Overview. Front Immunol. 2020; 11: 1416

PubMed Abstract | Publisher Full Text | Free Full Text

167. Mathys H, Adaikkan C, Gao F, et al:: Temporal Tracking of Microglia Activation in Neurodegeneration at Single-Cell Resolution. Cell Rep. 2017; 21(2): 366-80.

PubMed Abstract | Publisher Full Text | Free Full Text | Faculty Opinions Recommendation

168. Mathys H, Davila-Velderrain J, Peng Z, et al:: Single-cell transcriptomic analysis of Alzheimer's disease. Nature. 2019; 570 (7761): 332-7. PubMed Abstract | Publisher Full Text | Free Full Text | Faculty Opinions Recommendation

169. - Hammond TR, Dufort C, Dissing-Olesen L, et al.: Single-Cell RNA Sequencing of Microglia throughout the Mouse Lifespan and in the Injured Brain Reveals Complex Cell-State Changes. Immunity. 2019; 50(1): 253-271.e6. PubMed Abstract | Publisher Full Text | Free Full Text Faculty Opinions Recommendation

170. N Frigerio CS, Wolfs L, Fattorelli N, et al.: The Major Risk Factors for Alzheimer's Disease: Age, Sex, and Genes Modulate the Microglia Response to A $\beta$ Plaques. Cell Rep. 2019; 27(4): 1293-1306.e6. PubMed Abstract | Publisher Full Text | Free Full Text | Faculty Opinions Recommendation

171. Nasuda T, Sankowski R, Staszewski O, et al.: Spatial and temporal heterogeneity of mouse and human microglia at single-cell resolution. Nature. 2019; 566(7744): 388-92.

PubMed Abstract | Publisher Full Text | Faculty Opinions Recommendation

172. Boddaert J, Kinugawa K, Lambert JC, et al.: Evidence of a role for lactadherin in Alzheimer's disease. Am J Pathol. 2007; 170(3): 921-9. PubMed Abstract | Publisher Full Text | Free Full Text

173. C Geirsdottir L, David E, Keren-Shaul H, et al:: Cross-Species Single-Cell Analysis Reveals Divergence of the Primate Microglia Program. Cell. 2019; 179(7): 1609-1622.e16.

PubMed Abstract | Publisher Full Text | Faculty Opinions Recommendation

174. Böttcher C, Schlickeiser S, Sneeboer MAM, et al.: Human microglia regional heterogeneity and phenotypes determined by multiplexed single-cell mass cytometry. Nat Neurosci. 2019; 22(1): 78-90.

PubMed Abstract | Publisher Full Text

175. Harris JA, Devidze N, Halabisky B, et al.: Many neuronal and behavioral impairments in transgenic mouse models of Alzheimer's disease are independent of caspase cleavage of the amyloid precursor protein. $J$ Neurosci. 2010; 30(1): 372-81.

PubMed Abstract | Publisher Full Text | Free Full Text 